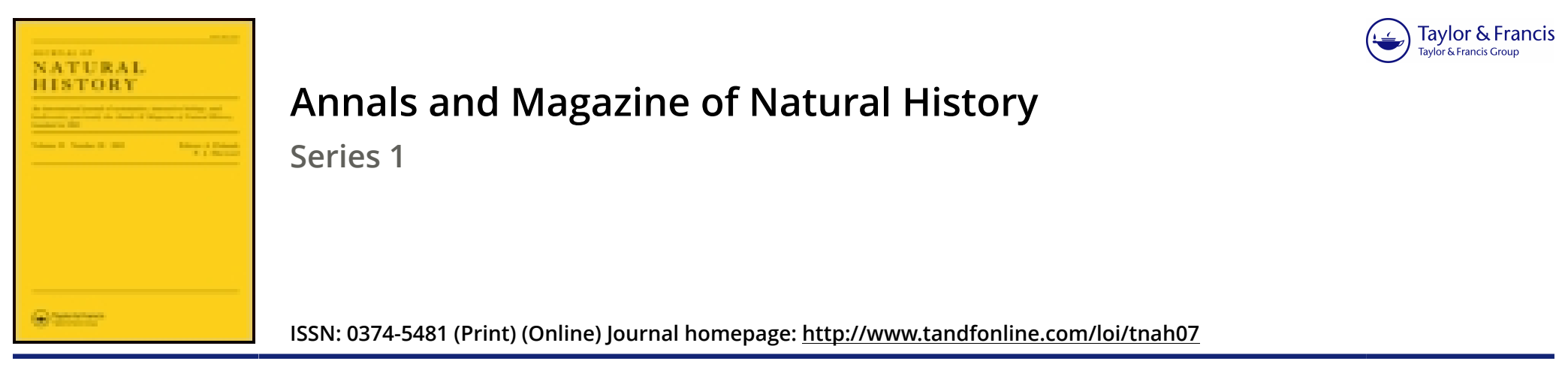

\title{
XXXV.-On Cyanocitta, a proposed new genus of Garrulinæ, and on C. superciliosa, a new species of blue Jay, hitherto confounded with C. ultramarina, Bonap
}

\section{H.E. Strickland M.A.}

To cite this article: H.E. Strickland M.A. (1845) XXXV.-On Cyanocitta, a proposed new genus of Garrulinæ, and on C. superciliosa, a new species of blue Jay, hitherto confounded with C. ultramarina, Bonap , Annals and Magazine of Natural History, 15:98, 260-261, DOI: 10.1080/037454809495311

To link to this article: http://dx.doi.org/10.1080/037454809495311

\section{Published online: 23 Dec 2009.}

Submit your article to this journal ए

View related articles $\sqsubset$ 
$260 \mathrm{Mr} . \mathrm{H}$. E. Strickland on a proposed new genus of Garrulinæ.

gin of the whorls, and the septa being foliated on the edge. I am aware that this opinion is not in conformity with the ideas of many zoologists and comparative anatomists, for $\mathrm{Mr}$. Owen, in the last arrangement of these animals (Todd. Ency. Comp. Anat.), though he places the Spirulce with the Dibranchiate Cephalopods, places the Ammonites with Tetrabranchiate next to Nautilus, with the following character, " animal unknown, presumed to resemble the Nautilus."

It is very desirable that other specimens of this animal should be preserved and brought to Europe, that we may have the opportunity of examining its internal structure, for I can fully sympathize with Mr. Cuming in not wishing to have the single specimen which he possesses in any way injured or cut.

\section{EXPLANATION OF PLATE $X V$.}

Fig. 1. The back of the animal.

Fig. 2. The ventral surface with the anal tube.

Fig. 3. The side, showing the shell, the dorsal and ventral process of the mantle and the anal tube.

Fig. 4. Extremity of the body, with the gland and its central aperture as contracted in spirits.

Fig. 5. The figure copied from Lamarck's sketch, ' Enc. Méthodique.'

Fig. 6. Animal and shell, copied from De Blainville's 'Manuel.'

Fig. 7. The figure copied from Peron and Lesueur's 'Atlas.'

XXXV.-On Cyanocitta, a proposed new genus of Garrulinæ, and on C. superciliosa, a new species of Blue Jay, hitherto confounded with C. ultramarina, Bonap. By H. E. StrickLand, M.A.

I LAtely received from Prof. Brandt of St. Petersburg a bird from California, labelled "Corvus ultramarinus, Audub., pl. 362. fig. 3," but which was evidently distinct from the true C. ultramarinus of the Prince of Canino. The latter species is found in Mexico, and has received the synonymous names of Garrulus sordidus, Swainson, and Pica Sieberi, Wagler. It is nearly uniform blue above without any superciliary mark, and cinereous below, becoming whitish on the belly and vent. In the bird from California on the contrary the dorsal feathers are cinereous brown; above the eye and ear-coverts is a narrow row of white dots; the cheeks are blackish with a bluish tinge on the lower part; the chin and throat white, faintly streaked with gray, the sides of each feather being margined with the latter colour. The blue of the crown and nape descends on each side and forms a collar around the white of the throat. The rest of the lower parts are very light brownish ash-colour. The wings and tail are blue as in C. ultramarina, with which it agrees in general form, except that the wings are much shorter. Total length 11 inches; beak 
to front 1 inch, to gape $1 \frac{1}{4}$ in. ; wing $4 \frac{1}{2}$ in. ; medial rectrices 5 in., external ditto $4 \frac{3}{6}$ in.; tarsus $1 \frac{1}{2}$ in.

This bird is accurately figured by Audubon in his ' Birds of America,' pl. 362. fig. 3, and described in his 'Ornithological Biographies' and 'Synopsis of the Birds of N.America,' but he erroneously refers it to the Garrulus ultramarinus of the Prince of Canino. The Prince himself also appears not to have detected this error, as he quotes Audubon's plate under his Cyanocorax ultramarinus in the 'Comparative List of the Birds of Europe and North America.' As however the present bird is elearly distinct, and, as far as I am aware, unnamed, I would propose for it the specitic name of superciliosa.

This species is more nearly allied in plumage to the Cyanocorax floridanus than to the ultramarinus. The floridanus is however distinguished, as Audubon remarks, by its smaller size, more rounded tail, and whitish band on the forehead, extending thence over the eye.

The birds of which I have been treating appear to be in want of a generic name. They stand in the same relation to the South American genus Cyanocorax, typified by C.pileatus, and of which Cyanurus, Swains., is a synonym, which Garrulus bears to Corvus, being essentially Blue Jays, while the species pileatus, cristatellus, peruvianus, azureus, cyanopogon, and one or two others composing Cyanocorax, are Blue Crows. Mr. G. R. Gray's genus Calocitta (typified by C. Bullocki, and perhaps including the Asiatic species erythrorhynchus) is distinguished by great length of tail, and there is consequently no generic name for these Blue Jays, which I would therefore propose to name Cyanocitta, taking $C$. cristata, Iinn. sp., as the type, and including the species ultramarina, Bonap., superciliosa, mihi, floridana, Bartram, stelleri, Pall., coronata, Swains., and probably a few others. The beak is much more slender, more depressed, and the culmen straighter than in Cyanocorax.

XXXVI.-Note on Mr. W. Thompson's Paper on the Ova of the Large Spotted Dog-fish. By Capt. Portuock, R.E.

Corfu, Jan. 23, 1845.

ON receiving this paper, I turned to a large collection of the ova of dog-fish which I had purchased from the fishermen in May 1844, and at the time classed as ova of Scyllium Catulus, the large spotted dog-fish, both on account of the great difference between them and the ova of either S. Canicula or of Pristiurus melanostomus, and from the fact that the Scyllium Catulus is the common species of Corfu. The resemblance in form between 